\title{
Nitro and aminobenzimidazoles
}

\author{
Viktor Milata \\ Institute of Organic Chemistry, Catalysis and Petrochemistry, Faculty of Chemical and Food Technology, \\ Slovak Technical University, Radlinského 9, SK-812 37 Bratislava, Slovak Republic \\ viktor.milata@stuba.sk
}

\begin{abstract}
A summary of the preparation methods of 2 tautomeric and $4 \mathrm{~N}$-methylated benzimidazoles with a nitro group on the benzene ring (1-6) and with an amino group in the same positions (7-12) were summarized. Annular tautomerism of the title compounds $\mathbf{1 - 1 2}$ has been studied using ${ }^{1} \mathrm{H},{ }^{13} \mathrm{C}$ and ${ }^{15} \mathrm{~N}$ NMR spectra in liquid and solid state (CPMAS), UV spectra and quantum chemical calculations.
\end{abstract}

Keywords: X-Nitro-1-methylbenzimidazoles, X-amino-1-methylbenzimidazoles, NMR, preparations, annular tautomerism

\section{Introduction}

Amines are very useful starting materials for many organic syntheses of heterocycles. In case when the aminogroup on the benzene ring is attached to a heterocycle, fused quinolines are obtained ( $\mathrm{Li} \mathrm{JJ}$, 2009). Their preparation is based mainly on the reduction of the corresponding nitroderivatives. Because the imidazole ring displays tautomerism, also its benzocondensed analogues with a substituent on the benzene nucleus are suitable for studying tautomerism, considering that prototropy of the imidazole nucleus can be eliminated by introducing a substituent at the nitrogen atom. Thus, a displacement of prototropic hydrogen from the imidazole ring for a methyl group eliminates the prototropy and does not significantly change chemical shifts in the ${ }^{13} \mathrm{C}$ NMR spectra (Fruchier et al., 1980). Therefore, benzimidazoles represent a typical annelated tautomeric system characterized by equilibrium constant $\mathrm{K}_{\mathrm{T}}$ (Elguero et al., 1976):

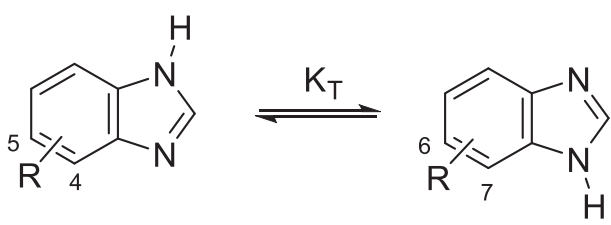

4(7)- or 5(6)-R-benzimidazoles

\section{Results and Discussion}

This review is focused on the preparation of benzimidazoles with a nitro- or aminogroup on the benzene ring of benzimidazole with tautomeric hydrogen on the imidazole nucleus or their $N$-methylated homologues with eliminated tautomerism. In the first part, preparation of nitrobenzimidazoles $\mathbf{1 - 6}$ (Fig. 1) by: 1) nitration of the ( $N$-methyl)benzimidazole derivative, 2) methylation of nitrobenzimidazole, or 3) cycliza- tion of a suitable substituted phenylenediamine (Bella et al., 2008) is described.<smiles>O=[N+]([O-])c1cccc2[nH]cnc12</smiles>

$1 \mathrm{a}$<smiles>O=[N+]([O-])c1cccc2nc[nH]c12</smiles>

$1 b$ 4-nitro-1 $H$-benzimidazole

7-nitro-1 $H$-benzimidazole<smiles>O=[N+]([O-])c1ccc2[nH]cnc2c1</smiles>

$2 \mathrm{a}$<smiles>O=[N+]([O-])c1ccc2nc[nH]c2c1</smiles>

$2 b$ 5-nitro-1 $H$-benzimidazole

6-nitro-1 $H$-benzimidazole<smiles>Cn1cnc2c([N+](=O)[O-])cccc21</smiles>

3<smiles>Cn1cnc2cccc([N+](=O)[O-])c21</smiles>

4 4-nitro-1-methylbenzimidazole

7-nitro-1-methylbenzimidazole<smiles>Cn1cnc2cc([N+](=O)[O-])ccc21</smiles>

5<smiles>Cn1cnc2ccc([N+](=O)[O-])cc21</smiles>

6 5-nitro-1-methylbenzimidazole

6-nitro-1-methylbenzimidazole

Fig. 1. Nitrobenzimidazoles $\mathbf{1 - 6}$. 
The most easily available compound is 5(6)-nitrobenzimidazole (2) which can be synthesized by direct nitration of benzimidazole (Zincke et al., 1896; Rabinowitz et al., 1951) like the major product accompanied with 4(7)-isomer (1) or one isomer from 4-nitro-1,2-phenylenediamine (Van der Want 1947):<smiles>O=[N+]([O-])c1ccc2[nH]cnc2c1</smiles>

The second tautomeric isomer - 4(7)-nitrobenzimidazole is accesible by cyclization of 3-nitro-1,2phenylenediamine with formic acid (Van der Want, 1948; Rabinowitz et al., 1951):<smiles>Nc1cccc([N+](=O)[O-])c1N</smiles><smiles>O=C(O)C1CCCCC1[N+](=O)[O-]</smiles>

1

Nitration of 1-methylbenzimidazole under the conditions of benzimidazole nitration with concentrated nitric acid in concentrated sulfuric acid affords only a mixture of 5- and 6-nitro-1-methylbenzimidazoles in the ratio $49: 51$ (Milata et al., 1996):
No traces of 4- and 7-nitro-1-methylbenzimidazoles $\mathbf{3}, \mathbf{6}$ were detected in the reaction mixture.

Theoretical aspects of nitration of benzazoles have been studied using the MP2/cc-pVDZ treatment (Breza et al., 2005) and it was concluded that the formation of a 5(6)-nitro-isomer can be explained formally only by the imidazole ring acting as a metaorientating substituent. Benzimidazole can also exist in form of $1 \mathrm{H}$ - or $2 \mathrm{H}$-tautomer, but the equilibrium is predominantly shifted to the $1 H$-one. Therefore, $o$-quinonoid non-aromatic species and their protonated analogues are not present. The protonated $1 \mathrm{H}$-tautomer produces a species with an aromatic benzene ring. The protonated imidazole ring is not such a strong electron acceptor as the triazole ring (nitrated at position 4), and the aromaticity of the benzene ring is not violated.

The best available $N$-methyl isomer is 5-nitro1-methylbenzimidazole prepared by a three-step synthesis from cheap 2,4-dinitrochlorobenzene (Joseph et al., 1962; Leandri et al., 1955):

Instead of formic acid, triethyl orthoformate can be used (Ellis et al., 1974). Alkylation of 5(6)-nitrobenzimidazole described in literature as frequentioselective (Denmlow et al., 1993) lead to a mixture of 5-nitro-1-methyl- (4) and 6-nitro-1-methyl- (5) isomers, which separation is difficult (Milata et al., 1989). If other corresponding starting materials are not readily available (Leandri et al. 1955), the preparation of 6-nitro-1-methylbenzimidazole (5) is most<smiles>Cn1cnc2ccccc21</smiles><smiles>Cn1cnc2cc([N+](=O)[O-])ccc21</smiles>

4<smiles>Cn1cnc2ccc([N+](=O)[O-])cc21</smiles>

5<smiles>Cn1cnc2c([N+](=O)[O-])cccc21</smiles>

3<smiles>Cn1cnc2cccc([N+](=O)[O-])c21</smiles>

6<smiles>CNc1ccc([N+](=O)[O-])cc1[N+](=O)[O-]</smiles><smiles>CNc1ccc([N+](=O)[O-])cc1N</smiles> 
<smiles>Nc1ccc([N+](=O)[O-])cc1N</smiles><smiles>Cn1cnc2ccc([N+](=O)[O-])cc21</smiles>

5<smiles>Nc1cccc([N+](=O)[O-])c1N</smiles><smiles>COC(C)OC(C)Cl</smiles>

3

appropriately done by the reaction of 4-nitro-1,2phenylenediamine with formaldehyde in ethanol (Ellis et al., 1974; López-Alvarado et al., 1991):

The other isomer, 5-nitro-1-methylbenzimidazole (4) was not found in the reaction mixture (Ellis et al., 1974). In the same way, the corresponding 3-nitro derivative resulted in 4-nitro-1-methylbenzimidazole (3) (Milata et al., 1993) without traces of 7-nitro-1-methylbenzimidazole (6):

Cyclization of 1-methyl-3-nitro-1,2-phenylenediamine prepared from hardly obtainable 2,3-dinitroaniline (Leandri et al., 1955; Reddy et al., 1979) gave the same product as obtained by fractional crystallization of the mixture of methylation products of 4(7)-nitrobenzimidazole in alkaline media (Reddy et al., 1979).

The last isomer, 7-nitro-1-methylbenzimidazole (6), can be prepared by a multistep reaction involving 2,6-dinitrochlorobenzene (Leandri et al. 1955; Red- dy et al., 1979) or by methylation of 4(7)-nitrobenzimidazole (1) (Rabinowitz et al., 1951; Leandri et al., 1955; Reddy et al., 1979).

Nitrobenzimidazoles 1-6 have been subjected to regression analysis (Pappalardo et al., 1975) of the ${ }^{1} \mathrm{H}$ NMR chemical shifts (Table 1). Equilibrium constants for the annular tautomers of two pairs of nitrobenzimidazoles $(\mathbf{1}, \mathbf{2})$ were determined and substituent effects were statistically calculated employing the ${ }^{13} \mathrm{C}$ NMR chemical shifts (Table 2) (Fruchier et al., 1980) and UV spectra of 1-6 (Table 3) (Leandri et al., 1955). They show the influence of the substituent position on the benzene ring on the chromophore absorption:<smiles>CCn1cnc2cc([N+](=O)[O-])ccc21</smiles>

Tab. 1. ${ }^{1} \mathrm{H}$ NMR chemical shifts of X-nitrobenzimidazoles 1-6 in $\mathrm{CDCl}_{3} /$ acetone- $\mathrm{d}_{6} / \mathrm{CF}_{3} \mathrm{COOD}$.

\begin{tabular}{|c|c|c|c|c|c|c|}
\hline \multirow{2}{*}{ Benzimidazole } & \multicolumn{6}{|c|}{ Chemical shifts, $\delta \mathrm{ppm}$} \\
\hline & $\mathrm{H}-2$ & $\mathrm{H}-4$ & $\mathrm{H}-5$ & $\mathrm{H}-6$ & $\mathrm{H}-7$ & $\mathrm{NMe}$ \\
\hline $4(7)$-nitro & $\mathrm{i}$ & & $\mathrm{i}$ & $\mathrm{i}$ & $\mathrm{i}$ & \\
\hline \multirow[t]{2}{*}{1} & 8.45 & - & 8.06 & 7.44 & 8.17 & - \\
\hline & 9.44 & & 8.67 & 7.99 & 8.40 & \\
\hline 5(6)-nitro & $\mathrm{i}$ & $\mathrm{i}$ & & $\mathrm{i}$ & $\mathrm{i}$ & \\
\hline \multirow[t]{2}{*}{2} & 8.50 & 8.56 & - & 8.17 & 7.77 & - \\
\hline & 9.50 & 8.99 & & 8.71 & 8.20 & \\
\hline 4-nitro-1-methyl & 8.14 & & 8.17 & 7.41 & 7.73 & 3.99 \\
\hline \multirow[t]{2}{*}{3} & 8.35 & - & 8.05 & 7.43 & 7.98 & 4.02 \\
\hline & 9.39 & & 8.67 & 7.95 & 8.34 & 4.39 \\
\hline 5-nitro-1-methyl & 8.05 & 8.68 & & 8.24 & 7.55 & 3.90 \\
\hline \multirow[t]{2}{*}{4} & 8.30 & 8.53 & - & 8.20 & 7.68 & 4.02 \\
\hline & 9.38 & 8.87 & & 8.65 & 8.07 & 4.33 \\
\hline 6-nitro-1-methyl & 8.11 & 7.83 & 8.20 & & 8.37 & 3.96 \\
\hline \multirow[t]{2}{*}{5} & 8.37 & 7.78 & 8.15 & - & 8.45 & 4.07 \\
\hline & 9.38 & 8.13 & 8.65 & & 8.87 & 4.36 \\
\hline 7-nitro-1-methyl & 7.98 & 8.11 & 7.35 & 8.03 & & 4.09 \\
\hline \multirow[t]{2}{*}{6} & 8.27 & 8.21 & 7.37 & 8.00 & - & 4.05 \\
\hline & 9.28 & 8.30 & 7.89 & 8.46 & & 4.44 \\
\hline
\end{tabular}

Adopted from Pappalardo et al., 1975. i - insoluble. 
Tab. 2. ${ }^{13} \mathrm{C}$ NMR chemical shifts of X-nitrobenzimidazoles $\mathbf{1 - 6}$.

\begin{tabular}{lcccccccc}
\hline \multirow{2}{*}{ Benzimidazole } & \multicolumn{9}{c}{ Chemical shifts, $\delta$ ppm, in DMSO-d } \\
& C-2 & C-4 & C-5 & C-6 & C-7 & C-3a & C-7a & NMe \\
\hline 4(7)-nitro & 145.2 & $133.8^{c}$ & 118.9 & 121.2 & $126.6^{c}$ & $145.4^{c}$ & $128.0^{c}$ & - \\
5(6)-nitro & 146.7 & 112.7 & 142.8 & 117.6 & 114.9 & 138.6 & 141.7 & - \\
4-nitro-1-methyl & 148.2 & 138.5 & 117.4 & 121.7 & 118.3 & 136.4 & 137.4 & 31.2 \\
5-nitro-1-methyl & 148.7 & 115.5 & $142.8^{*}$ & 117.8 & 110.9 & $142.5^{*}$ & 139.4 & 31.2 \\
6-nitro-1-methyl & 149.8 & 119.6 & 117.0 & 142.8 & 107.6 & 147.8 & 134.4 & 31.2 \\
7-nitro-1-methyl & 149.0 & 138.5 & 117.4 & 121.7 & 118.3 & 136.4 & 137.4 & 35.1 \\
\hline
\end{tabular}

Adopted from Fruchier et al., 1980. 'Broad. *Chemical shifts can be reversed.

Tab. 3. UV spectra of nitrobenzimidazoles $\mathbf{1 - 6}$ in ethanol solutions.

\begin{tabular}{ccc}
\hline Compound & \multicolumn{2}{c}{$\lambda_{\max } / \log \varepsilon$} \\
\hline $\mathbf{1}$ & $220 / 3.92$ & $315-318 / 3.93$ \\
$\mathbf{2}$ & $235 / 4.30$ & $301-303 / 3.97$ \\
$\mathbf{3}$ & $221 / 3.95$ & $314-319 / 3.90$ \\
$\mathbf{4}$ & $239-240 / 4.34$ & $303-304 / 3.95$ \\
$\mathbf{5}$ & $238-239 / 4.23$ & $302 / 4.04$ \\
$\mathbf{6}$ & $225 / 3.79$ & $313-318 / 3.72$ \\
\hline
\end{tabular}

Adopted from Leandri et al., 1955.

The corresponding amines 7-12 (Fig. 2) were synthesized using stannous chloride (LópezAlvarado et al., 1991) or by catalytic reduction with catalysts: Adams (Ellis et al., 1974), Raney or $\mathrm{Pd} / \mathrm{C}$ (Garcia et al., 2009). The synthesis of 4-amino-1-methylbenzimidazole (9) from 2,6-dinitroaniline or 1,2,3-triaminobenzene using rational approach has been reported recently (Van der Want, 1947; Efros, 1953; Marcos et al., 1991). 5(6)-Aminobenzimidazole (8) was prepared from 1,2,4-triaminobenzene upon its cyclization with formic acid (Van der Want, 1947) and 7-amino1-methylbenzimidazole (12) was prepared from 2,6-dinitro- $N$-methylaniline (Efros et al., 1957). Alkylation of aminobenzimidazoles also affords mixtures of regioisomers (Howell et al., 1993; Haque et al., 1994). Basicity of the benzimidazole ring/amino group were measured (Efros, 1953) for $4(7)$-aminobenzimidazole $(7)\left(\mathrm{p} K_{\mathrm{b}}=8.7 / 12.5\right)$ and 5(6)-tautomer $(8)\left(\mathrm{p} K_{\mathrm{b}}=7.4 / 10.7\right)$ and (Efros et al., 1957) for 7-amino-1-methylbenzimidazole (12) $\left(\mathrm{p} K_{\mathrm{b}}=8.21 / 11.65\right)$ and 5 -aminoisomer (10) $\left(\mathrm{p} K_{\mathrm{b}}=7.79 / 11.71\right)$ (Fig. 2).

Amines and especially heterocyclic ones are readily oxidized in air which complicates their study (Lythgoe et al., 1993). 5(6)-Aminobenzimidazoles were found to form stable hydrates (Kada et al., 1974). Literature results on annular tautomerism of NH-

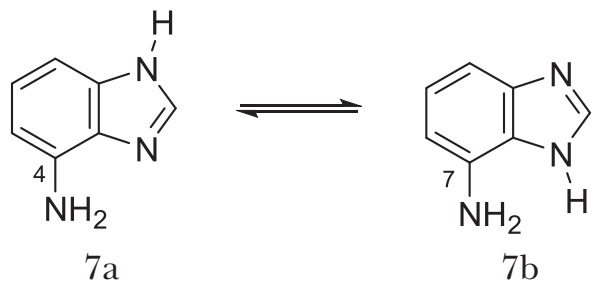

4-amino- $1 H$-benzimidazole

7-amino-1 $H$-benzimidazole<smiles>Nc1ccc2[nH]cnc2c1</smiles>

$8 \mathrm{a}$

$8 b$

5-amino-1 $H$-benzimidazole

6-amino- $1 H$-benzimidazole<smiles>Cn1cnc2c(N)cccc21</smiles>

9<smiles>Cn1cnc2cccc(N)c21</smiles>

10 4-nitro-1-methylbenzimidazole

7-nitro-1-methylbenzimidazole<smiles>Cn1cnc2cc(N)ccc21</smiles>

11<smiles>Cn1cnc2ccc(N)cc21</smiles>

12 5-nitro-1-methylbenzimidazole

6-nitro-1-methylbenzimidazole

Fig. 2. Aminobenzimidazoles 7-12.

benzimidazoles are scarce. While 4(7)-aminobenzimidazole (7) exists in DMSO- $\mathrm{d}_{6}$ (Table 4 ) only as the $1 \mathrm{H}$ - and not $7 \mathrm{H}$-tautomer (also 4 -amino- $1 \mathrm{H}$ - and 
Tab. 4. ${ }^{13} \mathrm{C}$ NMR chemical shifts of aminobenzimidazoles 7-12 in DMSO- $\mathrm{d}_{6}$ ( $\delta$ in ppm).

\begin{tabular}{lcccccccc}
\hline Compound & C-2 & C-3a & C-4 & C-5 & C-6 & C-7 & C-7a & $N-M e$ \\
\hline $\mathbf{7 a}$ & 138.9 & 131.9 & 139.9 & 103.9 & 123.2 & 99.3 & 133.7 & - \\
$\mathbf{9}$ & 141.5 & 132.1 & 140.1 & 104.3 & 123.4 & 97.6 & 135.2 & 30.6 \\
$\mathbf{1 0}$ & 144.3 & 145.4 & 109.0 & 122.2 & 108.6 & 135.3 & 124.1 & 33.2 \\
$\mathbf{8 a}$ & 140.8 & ca. $145^{\mathrm{a}}$ & 102.5 & ca. $146^{\mathrm{a}}$ & 111.2 & 111.2 & ca. $^{127}(\mathrm{br})^{\mathrm{a}}$ & - \\
$\mathbf{8 b}$ & 138.9 & 134.5 & 118.9 & 111.2 & 144.7 & 94.7 & 135.3 & - \\
$\mathbf{1 1}$ & 143.5 & 144.6 & 102.6 & 143.9 & 112.1 & 109.8 & 127.3 & 30.5 \\
$\mathbf{1 2}$ & 141.6 & 135.5 & 119.3 & 111.1 & 144.9 & 92.9 & 135.8 & 30.2 \\
\hline
\end{tabular}

${ }^{a}$ These signals are under the signals of the most abundant tautomer.

not 7 -amino- $1 H$-tautomer), but in HMPA-d $\mathrm{d}_{18}$ (Table 5) as both tautomers.<smiles>CCn1cnc2cc(N)ccc21</smiles>

4(7)-Aminobenzimidazole (7) was studied by a combination of theoretical (B3LYP/6-31++G**) and matrix-isolation FT-IR methods (Ramaekers et al., 2003; Houben et al., 2004). In the Ar matrix, only monomers exist. Main conclusions of the study by Garcia et al. (2009) are: i) a mixture of 7a $78 \% / 7 \mathbf{b} 22 \%\left(K_{\mathrm{T}}=0.28, \Delta G_{298}=3.1 \mathrm{~kJ} \mathrm{~mol}^{-1}\right.$ is present in the matrix; ii) according to the calculations, $\Delta G_{340}=15.5 \mathrm{~kJ} \mathrm{~mol}^{-1}\left(K_{\mathrm{T}}=0.004,7 \mathbf{a} 0.4 \% / 7 \mathbf{b}\right.$ $99.6 \%$ ); iii) large difference between the experiment and calculation can be attributed to the presence of water in the matrix which, according to authors,

Tab. 5. ${ }^{13} \mathrm{C}$ and ${ }^{15} \mathrm{~N}$ NMR chemical shifts of aminobenzimidazoles 7 and 8 in HMPA-d $\mathrm{H}_{18}(\delta$ in ppm).

\begin{tabular}{|c|c|c|c|c|}
\hline Compd. & $\begin{array}{c}7 \mathbf{a} \\
(60 \%) \\
(300 \mathrm{~K})\end{array}$ & $\begin{array}{c}\mathbf{7 b} \\
(40 \%) \\
(300 \mathrm{~K})\end{array}$ & $\begin{array}{c}8 \mathbf{a} \\
(17 \%) \\
(283 \mathrm{~K}) \\
\end{array}$ & $\begin{array}{c}\mathbf{8 b} \\
(83 \%) \\
(283 \mathrm{~K}) \\
\end{array}$ \\
\hline C-2 & $138.4^{\mathrm{a}}$ & $139.4^{c}$ & 140.2 & 138.1 \\
\hline C-3a & 133.2 & 144.8 & 143.1 & 136.0 \\
\hline C-4 & 141.2 & 106.8 & 103.1 & 118.7 \\
\hline C-5 & 103.8 & 121.7 & 143.1 & 111.2 \\
\hline C-6 & 122.9 & 105.2 & 110.2 & 146.5 \\
\hline C-7 & 99.0 & 136.0 & 112.7 & 94.8 \\
\hline C-7a & 134.6 & 123.6 & 126.2 & 135.1 \\
\hline N-1 & $-234.3^{\mathrm{b}}$ & $-229.4^{\mathrm{d}}$ & -232.3 & -232.3 \\
\hline N-3 & -134.0 & -141.5 & -136.4 & -136.4 \\
\hline $\mathrm{NH}_{2}$ & -328.5 & -328.5 & -324.4 & -324.4 \\
\hline
\end{tabular}

${ }^{\mathrm{a}}{ }^{1} J_{\mathrm{CH}}=203.1$;

${ }^{\mathrm{b} 1} J_{\mathrm{NH}}=96.9$;

${ }^{\mathrm{c} 1} J_{\mathrm{NH}}=86.6$

${ }^{\mathrm{d} 1} J_{\mathrm{NH}}=96.0$ (Adopted from Garcia et al., 2009). should stabilize the minor isomer; iv) non-planarity of the amino groups was found.

In the solid state (Tables 6 and 7), the tautomeric composition should be simpler. Only one tautomer or a 50/50 mixture of tautomers are expected; the first case being the most common one. Very rare occurrence of 33/66 trimers or 25/75 tetramers is known (Claramunt et al., 2006; Cornago et al., 2009). The results in Table 6 correspond to 4(7)-aminobenzimidazole (7) existing in the solid state as the 4 -amino tautomer $(\mathbf{7 a})$, which is the expected result, and 5(6)-aminobenzimidazole (8) existing in the solid state as a 50/50 mixture of 5 -aminotautomer $(\mathbf{8 a})$ and 6 -amino- $1 H$-tautomers (8b). Since the difference in energy is small, this result is not in contradiction with the calculations (see below) nor with the results obtained in a solution, however this is the first example of benzimidazole crystallizing as a mixture of tautomers. A search in the CSD proved that there is no example of the existence of benzimidazole tautomer pairs in crystals (Allen, 2002).

Solid-state ${ }^{15} \mathrm{~N}$ NMR results in Table 7 are not very useful in regard to tautomerism partly because most $N$-methyl derivatives presented splitted signals due to crystal packing effects and partly because isomerism did not produce significant effects on any of the three nitrogen signals. Compound 7 showed only three signals consistent with only one tautomer. The signals of $\mathrm{N}_{1}$ and $\mathrm{N}_{3}$ of compound 8 are splitted and the signal at -229.8 ppm probably corresponds to $\mathbf{8 b}$ and at -225.7 to $\mathbf{8 a}$.

Minimum-energy-calculated geometries at the B3LYP/6-311++G(d,p) level within the G03 package of all compounds correspond to nonplanar amino groups, as it has been found by other authors for $\mathbf{7 a}$ and $\mathbf{7 b}$ (Houben et al., 2004). The difference is smaller and in favor of the other tautomer in case of $\mathbf{8}$. The first difference at $298.15 \mathrm{~K}$ corresponds to $99.85 \%$ of $\mathbf{7 a}$ and $0.15 \%$ of $\mathbf{7 b}$; the second one, to $28 \%$ of $\mathbf{8 a}$ and $72 \%$ of $\mathbf{8 b}$. Garcia et al. (2009) calculated the absolute shieldings for all compounds within the GIAO approximation. 
Tab. 6. ${ }^{13} \mathrm{C}$ CP MAS NMR chemical shifts of aminobenzimidazoles 7-12 ( $\delta$ in ppm).

\begin{tabular}{|c|c|c|c|c|c|c|c|c|}
\hline Compound & $\mathrm{C}-2$ & C-3a & $\mathrm{C}-4$ & C-5 & C-6 & C-7 & C-7a & $\mathrm{N}$-Me \\
\hline $7 a$ & 139.6 & $131.2^{\mathrm{a}}$ & $137.1^{\mathrm{a}}$ & 103.1 & 121.6 & 103.1 & $133.3^{\mathrm{a}}$ & - \\
\hline \multirow[t]{3}{*}{9} & 140.8 & $131.6^{\mathrm{a}}$ & $140.1^{\mathrm{a}}$ & 106.5 & 127.4 & 98.2 & $135.0^{\mathrm{a}}$ & 29.8 \\
\hline & & & & 105.6 & 123.8 & 97.0 & & \\
\hline & & & & 103.0 & 122.6 & 95.3 & & \\
\hline \multirow[t]{2}{*}{10} & 145.5 & $145.4^{\mathrm{a}}$ & 108.8 & 123.7 & 112.7 & $135.8^{\mathrm{a}}$ & $126.7^{\mathrm{a}}$ & 33.4 \\
\hline & & & 110.5 & 121.1 & & & $124.6^{\mathrm{a}}$ & 32.5 \\
\hline $8 \mathbf{a}(50 \%)$ & 142.0 & $142.5^{\mathrm{a}}$ & 99.5 & $136.7^{\mathrm{a}}$ & 111.2 & 119.5 & $134.0^{\mathrm{a}}$ & - \\
\hline $8 \mathbf{b}(50 \%)$ & 140.8 & $133.0^{\mathrm{a}}$ & 118.7 & 112.2 & $144.7^{\mathrm{a}}$ & 94.6 & $136.7^{\mathrm{a}}$ & \\
\hline 11 & 146.1 & $144.7^{\mathrm{a}}$ & 101.5 & $144.7^{\mathrm{a}}$ & 111.8 & 111.8 & $128.0^{\mathrm{a}}$ & 30.3 \\
\hline 12 & 142.2 & $134.2^{\mathrm{a}}$ & 118.9 & 109.7 & $146.9^{\mathrm{a}}$ & 91.9 & $136.3^{\mathrm{a}}$ & 29.7 \\
\hline
\end{tabular}

${ }^{a} \mathrm{NQS}$ signals. ${ }^{13} \mathrm{C}$ spectra were originally referenced to a glycine sample and then the chemical shifts were recalculated to $\mathrm{Me}_{4} \mathrm{Si}$ [for the carbonyl atom $\delta$ (glycine) $=176.1 \mathrm{ppm}$ ]. (Adopted from Garcia et al., 2009.)

Tab. 7. ${ }^{15} \mathrm{~N}$ CP MAS NMR chemical shifts of aminobenzimidazoles 7-12 ( $\delta$ in ppm).

\begin{tabular}{cccc}
\hline Compound & $\mathrm{N}_{1}$ & $\mathrm{~N}_{3}$ & $\mathrm{NH}_{2}$ \\
\hline $\mathbf{7 a}$ & -217.7 & -149.9 & -323.7 \\
\hline $\mathbf{9}$ & $-229.8,-233.8$ & -143.7 & -321.5 \\
\hline $\mathbf{1 0}$ & -232.3 & $-138.5,-141.4$ & -325.3 \\
\hline $\mathbf{8} \mathbf{a} \mathbf{8 b}$ & $-229.8,-225.7$ & $-143.8,-149.4$ & -323.4 \\
\hline $\mathbf{1 1}$ & -232.0 & -142.1 & $-320.5,-322.9$ \\
\hline $\mathbf{1 2}$ & -234.9 & -142.2 & -319.2 \\
\hline
\end{tabular}

${ }^{15} \mathrm{~N}$ spectra were referenced to ${ }^{15} \mathrm{NH}_{4} \mathrm{Cl}$ and then converted to the nitromethane scale using the relationship: $\delta^{15} \mathrm{~N}$ (nitrometh ane $)=\delta^{15} \mathrm{~N}($ ammonium chloride $)-338.1 \mathrm{ppm}$. (Adopted from Garcia et al., 2009.)

\section{Conclusions}

In this review, an overview of ambiguous and unambiguous methods of the synthesis of tautomeric and the corresponding non-tautomeric methylated nitro- and aminobenzimidazoles with a substituent on the benzene ring is presented. Tautomerism has been studied using ${ }^{1} \mathrm{H},{ }^{13} \mathrm{C}$ and ${ }^{15} \mathrm{~N}$ NMR spectra in liquid and solid state (CP MAS technique) and compared with quantum chemical calculations. 4(7)-Nitrobenzimidazole (1) exists in solution in form of the dominating tautomer 7-nitro- $1 H$-benzimidazole (1b) $(85 \pm 6 \%)$ and its 5(6)-isomer (2) as the major tautomer 6-nitro- $1 \mathrm{H}$ benzimidazole (2b) (62 $\pm 2 \%)$. While 5(6)-aminobenzimidazole (8) exists in a 50/50 mixture of both tautomers $(\mathbf{8 a}: \mathbf{8 b}), 4(7)$-isomer (7) exists in solid state as 4 -amino- $1 H$-tautomer (7a). In HMPA- $\mathrm{d}_{18}$, 4- : 7-amino- $1 H$-benzimidazole are present in the ratio of $60: 40$ and 5-: 6-amino-1H-benzimidazole, surprisingly, in the ratio of $17: 83$.

\section{Acknowledgement}

This work was supported by the Slovak Research and Development Agency (APVV-17-0513), EU structural funds as a part of the Security Research Centre of Excellency
ITMS 26240120034, a grant from the Research Center for Industrial Synthesis of Drugs, ITMS 26240220061, and by the Research and Development Operational Programme funded by the ERDF.

\section{References}

Bella M, Milata V (2008) J. Heterocycl. Chem. 45: 425-427.

Claramunt RM, Cornago P, Santa María MD, Torres V, Pinilla E, Torres MR, Elguero J (2006) Supramol. Chem. 18: 349-356.

Cornago P, Cabildo P, Claramunt RM, Bouissane L, Pinilla E, Torres MR, Elguero J (2009) New J. Chem. 33: $125-135$. 10.1039/b812018h, CSD version 5.29, January 2008 update.

Allen FH, Acta Crystallogr. Sect. B 2002; B58: 380-388.

Allen FH, Motherwell WDS, Acta Crystallogr. Sect. B 2002; B58: 407-422.

Denmlow EV, Richter R, Zhivich AB (1993) J. Chem. Res. (S) 504-505.

Efros LS (1953) J. Gen. Chem. 23: 957-963 (translated p. 995).

Efros LS, Ionin BI (1957) J. Gen. Chem. 27: 406411 (translated p. 459).

Elguero J, Marzin C, Katritzky AR, Linda P (1976) The Tautomerism of Heterocycles, Adv. Heterocyclic Chem., Academic Press, New York, Suppl. 1: 266300 . 
Ellis GP, Jones RT (1974) J. Chem. Soc. Perkin Trans. I, 903-909.

Fruchier A, Pappalardo L, Elguero J (1980) Ann. Quim. 76: 79-84.

Garcia MÁ, Claramunt RM, Solčan T, Milata V, Alkotra I, Elguero J (2009) Magn. Reson. Chem. 47: 100-104.

Haque MR, Rasmussen M (1993) Aust. J. Chem. 47: 1523-1526.

Houben L, Ramaekers R, Adamowicz, Maes G (2004) Internet Electron. J. Mol. Des. 3: 163-181, http:// www.biochempress.com.

Howell JR, Rasmussen M (1993) Aust. J. Chem. 46: $1177-1191$.

Joseph L, Julca J (1962) J. Org. Chem. 27: 1101-1102.

Kada R, Jurášek A, Kováč J, Králik P (1974) Chem. Zvesti 28: 391-395.

Leandri G, Mangini A, Montanari F, Passerini R (1955) Gazz. Chim. Ital. 85: 769-814.

Li JJ (2009) Gould-Jacobs reaction. In: Name Reactions: A Collection of Detailed Mechanisms and Synthetic Applications (4th ed.). Springer-Verlag. p 263 doi: 10.1007/978-3-642-01053-8_113. ISBN 9783642010538.
López-Alvarado P, Avendaño C, Menéndez JC (1991) Heterocycles 32: 1003-1012.

Lythgoe DJ, McClenaghan I, Ramsden CA (1993) J. Heterocycl. Chem. 30: 113-117.

Marcos A, Pedregal C, Avendaño C (1991) Tetrahedron 47: 7459-7464.

Milata V, Ilavský D (1993) Org. Prep. Proc. Int. 25: 703-704.

Milata V, Ilavský D (1996) Bull. Soc. Chim. Belg., 105: 213-214.

Milata V, Ilavský D, Goljer I (1989) Coll. Czech. Chem. Commun. 54: 713-724.

Pappalardo L, Elguero J, Fruchier A (1975) An. Quim. 71: 598-602.

Rabinowitz JL, Wagner EC (1951) J. Amer. Chem. Soc. 73: 3030-3035.

Ramaekers R, Houben L, Adamowicz, Maes G (2003) Vibrat. Spectrosc. 32: 185-197.

Reddy VM, Reddy K (1979) Indian J. Chem. 17B: 357-359.

Van der Want (1947) Rec.Trav. Chim. 67: 45-51.

Zincke T, Helmert B (1896) J. Prakt. Chem. 2, 53: 91-106. 